\title{
Group dynamic assessment of EFL listening comprehension: Conversational implicatures in focus
}

\author{
Hashemi Shahraki, Sara $\square$ \\ English Department, University of Isfahan, Iran (sara_m_hashemi@yahoo.com) \\ Ketabi, Saeed \\ English Department, University of Isfahan, Iran (ketabi@fgn.ui.ac.ir) \\ Barati, Hossein \\ English Department, University of Isfahan, Iran (h.barati@gmail.com)
}

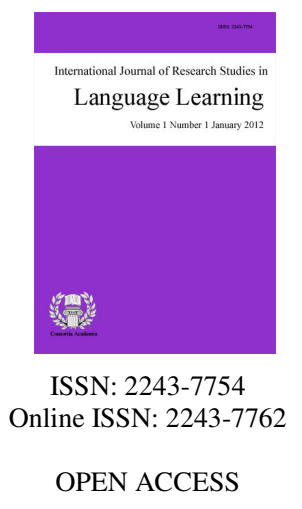

\section{Abstract}

While the teachability of second language (L2) pragmatics has been the subject of considerable recent research interest (e.g. Bardovi-Harlig, 2011; Murray, 2011), testing the ability to infer implicatures in L2 has received limited attention (Roever, 2006). This study, therefore, tested the applicability of Group dynamic assessment (G-DA), rooted in Vygotskian socio-cultural theory (SCT), in assessing intermediate learners' pragmatic knowledge of conversational implicatures in the context of listening while simultaneously identifying the mediational strategies that can nurture the development of this knowledge. To this end, 50 English as Foreign Language (EFL) learners of two intermediate intact classes at a language institute in Iran were selected to participate in this study (experimental group=24 and control group=26). Both groups went through a multi-assessment procedure in the format of dynamic and non-dynamic pretest -enrichment phase- dynamic and non-dynamic posttest. Only the experimental group received mediational support during the ten-week G-DA procedure. The study employed both qualitative and quantitative data analyses. The qualitative analysis of G-DA interactions led to the detection of nine mediational strategies ranging in their degree of explicitness. Moreover, both qualitative and quantitative data analyses revealed that the mediational support offered resulted in significant changes in the listening ability of the learners improving their pragmatic understanding of conversational implicatures. The findings may be revealing in that they support G-DA and its applicability to Second Language (L2) listening comprehension and pragmatics instruction.

Keywords: group dynamic assessment; socio-cultural theory; conversational implicatures; listening comprehension; intermediate EFL learners 


\section{Group dynamic assessment of EFL listening comprehension: Conversational implicatures in focus}

\section{Introduction}

In recent years, a number of language testing studies have attempted to identify factors that influence variation in performance on listening comprehension tests (e.g. Révész \& Brunfaut, 2013; Tavakoli, Hashemi, \& Rezazadeh, 2012; Vandergrift \& Goh, 2009). However, it seems little attention is given to the diagnostic and dynamic assessment of this language skill (Ableeva, 2010). Language learners have often perceived listening comprehension to be the most difficult language skill to learn (Graham, 2006), yet worse the assessment of this skill has always haunted them (Bloomfield, Wayland, Rhoades, Blodgett, Linck, \& Ross, 2011). The recent pedagogical applications of Dynamic Assessment (DA) rooted in Vygotskian Socio-Cultural Theory (SCT), serving as both an instructional and an evaluative tool seems to have opened new horizons for teaching and assessment of listening comprehension. Through DA a teacher can diagnose developed abilities of a learner revealed through her/his independent performance, as well as abilities that are in the process of forming along with gaining insight of the sources of poor performance (Sternberg \& Grigorenko, 2002; Haywood \& Lidz, 2007).

Since the 1980s, DA has been implemented in psychological research and in educational research and has proven to be a valuable diagnostic tool (e.g. Feuerstein, Rand, Hoffman, \& Miller, 1980; Budoff, 1987). However, the pedagogical applications of DA have begun in L2 research within the last two decades (e.g. Abdolrezapour, Tavakoli, \& Ketabi, 2014; Ableeva, 2010; Antón, 2009; Kozulin, \& Garb, 2002; Poehner \& Lantolf, 2013). To date, not many DA studies have been done on the listening comprehension skill (Ableeva, 2010; Hidri, 2014). In a DA project carried out on L2 listening comprehension on university level intermediate learners of French, Ableeva (2010) detected ten types of mediational strategies throughout the interactions she had with the learners. The strategies were 1)Accepting Response; 2)Structuring the text; 3)Replay of a passage; 4)Asking the Words; 5)Identifying a Problem Area; 6)Metalinguistic Clues; 7)Offering a Choice; 8)Translation; 9)Providing a Correct Pattern; and 10)Providing an Explicit Explanation. Ableeva observed that causes of poor performance were sometimes the result of a lack of lexical knowledge of the L2, problems stemming from phonology, limited knowledge of the L2 culture and issues with discourse level grammar. She also witnessed that there were limits to what individuals were capable of doing under mediation. Hidri (2014) compared static and dynamic testing of L2 listening comprehension at university level. Her study revealed DA provided better insights into learners' cognitive and meta-cognitive processes than did the traditional static assessment.

In most of the studies done on L2 DA (e.g. Ableeva, 2010; Anton, 2009), researchers have favored a dyadic model with one teacher and one student. This form of administration, however, can be an unrealistic model for classroom teachers who have to typically manage a group of learners not only one individual. Since Vygotsky (1998) describes the Zone of Proximal Development (ZPD) as "the optimum time for teaching both the group and each individual" (p. 204), SCT practitioners agree that it is possible to have group dynamic assessment (G-DA) in which the mediator simultaneously offers mediation to a group of learners to help them co-construct a group's ZPD (Poehner \& Lantolf, 2005; Poehner, 2009). Some studies (e.g., Lantolf \& Poehner, 2011; Davin, 2013) have recently implemented DA procedures with groups of classroom L2 learners, but this matter has not yet been adequately addressed. A major challenge that has caused the classroom context to receive a small share of DA research is that it is not very clear how to apply DA in a place where the teacher interacts with not a single ZPD but a group of ZPDs (Haywood \& Lidz, 2007; Poehner, 2009).

An early attempt that was not overtly framed as a DA yet focused on co-constructing a group's ZPD by mediation is Gibbons (2003). The findings of her study revealed the ways students and teacher used to co-construct meaning in a shared experience had a great impact on students' progress stretching their ZPD to 
more complex domains. Lantolf and Poehner (2011) report on the efforts of an elementary school L2 Spanish teacher who implemented G-DA in her daily instructions to improve oral proficiency. The results showed learners' readiness to gain control over an L2 feature was not the same; it was gradual for some and abrupt for others. Moreover, the co-construction of a ZPD with an individual had the potential to push the development of the group of students forward. Another study in G-DA is Davin (2013) that reports on the efforts of an L2 Spanish teacher who integrated DA and instructional conversation (IC) within classroom setting to teach a grammatical structure. The findings of her study provided evidence of the compatibility of G-DA and the IC to promote development and improve assessment in the language classroom.

Another mind-boggling concern for L2 learners is their difficulty in the comprehension of forms of implicit meaning that commonly occurs in social discourse through the use of conversational implicatures leading some students to ask if they could be taught "the secret rules of English," (Bardovi-Harlig \& Mahan-Taylor, 2003, p. 32). Research into the pragmatic competence of language learners has revealed that grammatical development does not guarantee a corresponding level of pragmatic development (Bardovi-Harlig \& Dornyei, 1998) and that even advanced learners may fail to comprehend the intended intentions of speakers. During the past few decades, teaching pragmatics has been advocated among researchers since language learners' L2 performance shows that there is a demonstrated need for it, and instruction benefits pragmatic development in both production and comprehension (e.g. Bardovi-Harlig, 2011; Bardovi-Harlig \& Nickels, 2011, Kasper \& Schmidt, 1996; Rose \& Kasper, 2001).

Conversational implicature, an aspect of pragmatics, is defined by Grice (1975) as what is not directly said in an utterance, or even not strictly implied; however it is entailed by the utterance. Grice (1975) introduced four guiding maxims, the expectations of cooperative social behavior which are taken to be mutually understood during conversations, that of providing an appropriate amount of information (quantity); which he/she has adequate evidence to believe is true (quality); which is relevant to the topic at hand (relation); and in a way that does not set out deliberately to confuse (manner). When a speaker is flouting one of the maxims, the intent is to create an implicature. Then, the hearer is expected to notice the maxim has been breached, consider why this is the case, and infer the intended meaning together with any additional information retrievable from the way in which it was conveyed. Language classrooms have the potential to foster an atmosphere in which both input and interpretation could be provided to enrich the pragmatic awareness and understanding of language learners. The teachability of conversational implicatures in the classroom has been the subject of interest during the past few decades (Blight, 2002; Bouton, 1999; Kubota, 1995; Murray 2011; Taguchi, 2005). However, it seems the pragmatic understanding of language learners especially comprehension of conversational implicatures in a listening context has not yet been analyzed through dynamic assessment.

Considering that DA can function simultaneously as assessment and instruction through which teachers not only discover where learners encounter problems but also provide support to overcome them, the present study intends to examine the implementation of DA to groups of intermediate English Foreign Language (EFL) learners in classroom setting. Moreover, by implementing DA in the context of classroom, this study is an attempt to lead to some new insights on the nature of L2 listening which seeks to diagnose the sources of difficulties intermediate EFL learners encounter in L2 listening comprehension especially in their pragmatic understanding of conversational implicatures. More specifically, it intends to find out how to promote this type of pragmatic understanding in the learners. A quasi-experimental mixed method research design within the SCT-based interactionist G-DA approach was implemented in the present study to address the following research questions:

$>$ Does G-DA enhance the development of listening comprehension ability especially the pragmatic understanding of conversational implicatures among intermediate EFL learners?

> What mediational strategies in G-DA will nurture the development of intermediate EFL learners' listening comprehension ability when exposed to conversational implicatures? 


\section{Materials and Method}

\subsection{Participants}

The population under study included EFL learners who enrolled at a language institute in Iran. In order to select participants, the non-random purposive sampling method (Mackey \& Gass, 2005) was applied. Initially, 57 learners of two high-intermediate intact classes were selected. Learners were Persian native speakers and had taken English courses for three years in this institute. None had exposure to English apart from attending this English course and at their high schools. All participants were female and were in the age range of 14 -18. Based on the results of the the Quick Placement Test (QPT), 53 learners whose scores fell within the range of upper intermediate i.e. 40-47 were selected to participate in the study. Then, one class was considered as the experimental group and the other as the control group. Three of the participants were excluded from the study since they did not attend all sessions during the ten-week G-DA listening procedure. This left 24 participants in the experimental group and 26 in the control. Participants of the experimental group all consented to be audio and video recorded during each treatment session.

\subsection{Instruments}

Quick Placement Test (QPT) - The test developed by Oxford University Press and Cambridge ESOL (2001) consists of two parts: Part one (1-40) deals with simple grammar and vocabulary items which all candidates should answer. Part two (40-60) is concerned with a bit more difficult multiple choice items and a cloze test, which is for higher ability learners (Geranpayeh, 2003). All questions are in multiple choice formats. First, part one was administered; since all participants answered more than 35 items out of 40 items correctly, the participants also completed part two. The test has been validated in 20 countries by more than 6000 students and has a reliability (internal consistency) of $\alpha=0.9$.

The Interactions/Mosaic Listening Placement Test (McGraw-Hill ESL/ ELT College) - The Interactions/Mosaic Listening Placement Test was the pretest and posttest in this study. There are a total of fifty questions in multiple choice format in this test divided into four sections, each with a different type of listening and questions. Section one consists of ten question items; after the examinee hears each question, he/she should choose the best response (questions 1-10). Ten statement items are in section two; after each statement is heard the best conclusion must be selected (questions 11-20). There are ten short conversations in section three; after each conversation, one question must be answered (questions 21-30). Section four includes four longer selections; five questions about the listening should be answered after listening to each longer selection (questions 31-50). Each correct answer on the test receives 1 point. A pilot study of this test on 60 learners yielded the reliability of (cronbach $\alpha$ ) 0.94 . The criterion-related validity using the listening section of FCE test, a standard listening test for intermediate language learners, as the criterion was 0.75 .

Seven listening test tasks - The listening test tasks (LTT) were selected from Mosaic 1 Listening/Speaking (2008) $6^{\text {th }}$ edition books (McGraw-Hill ESL/ ELT College) from the section containing TOEFL like test tasks measuring pragmatic understanding. The reason for choosing this book was the scores of the participants of both groups on the pretest which were in the range of 33-42. Each listening text was either a part of a longer conversation or a number of short conversations having conversational implicatures; i.e. the speakers' attitudes, opinions or goals were not stated directly in their utterance accompanied with multiple-choice questions. They were used for the mediation phase of the G-DA procedure. A pilot study of the seven test tasks used in this study on 20 intermediate learners yielded the reliability of (cronbach $\alpha$ ) $0.73,0.80,0.84,0.87,0.85,0.92$, and 0.88 respectively. The tests also gained professional-judgment-based content validity (from a group of 5 expert judges at University of Isfahan). In this paper, length constraints preclude the discussion of all the test items. One item extracted from LTT1, describing the maxim which was violated is mentioned next: 
Student 3: How many languages are there in the world? And can we ever really learn to speak someone else's language?

Professor: Hummm... Anymore? No?

Narrator: $\quad$ Why does the professor say, "Anymore? No?"
a. so students will name as many languages as they can
b. to find out if all students are present
c. to find out if anyone else has a question
d. so he can complete a list of languages

In line 2, the maxim of relevance is violated. The professor's contribution to the conversation is not relevant since he wants to make sure if anyone else has a question or not.

\subsection{Procedure}

The pretest-enrichment phase-posttest format (following Ableeva, 2010 and Poehner, 2008) was administered in this study for a time span of 10 weeks as described below:

$>$ In week 1, the QPT (2001) was given to two intact upper intermediate classes, and based on the test results, those who were graded to be at upper intermediate level were selected to participate in this study. Then one class was assigned as the experimental group and the other as the control group.

$>\quad$ In week 2, The Interactions/Mosaic Listening Placement Test (McGraw-Hill ESL/ ELT College) was used as the pretest to the participants of both groups and also with the aim to homogenize the participants on their listening ability. The pretest was administered to the experimental group in dynamic and non-dynamic format.

$>\quad$ During weeks 3-9, the experimental group received the enrichment phase which took place in seven sessions once a week. In each session, first the participants of the experimental group answered an LTT individually. Then the test sheets were collected, and the listening text was replayed portion by portion for the class to provide their recalls. Upon the students' failure to recall the content of the portion, the teacher intervened and based on the ability of learners provided flexible mediations using the interactionist approach (Lantolf \& Poehner, 2004). To assure the active participation of all learners in the G-DA interactions, at the beginning of each session, the learners were told that their active presence and contributions in the class was essential to their learning and that being silent in class would be interpreted as an inability to understand the listening text. Each class meeting was audio and video recorded, and teacher-learner interactions were transcribed with the purpose of having access to all the mediating moves taken place during G-DA. The participants of the control group, during week 3-9, did not receive any mediation; however, they answered the 7 LTTs independently in order to eliminate the practice effects of the test materials (Mackey \& Gass, 2005).

$>\quad$ In week 10, the posttest was administered to both groups; however, the experimental group took this test in dynamic format as well. The pretest was used as the posttest to trace the effects of the mediation phase on the students' listening comprehension of conversational implicatures in the experimental group.

\section{Results}

Both qualitative and quantitative data analyses were used to answer the research questions which guided this study. 


\subsection{Quantitative data analysis}

The first research question intended to investigate whether G-DA can enhance the development of listening ability especially the pragmatic understanding of conversational implicatures among intermediate language learners. To answer this question, the pretest was given to the participants of both the experimental and control group, and then the same test was given to the participants of both groups 8 weeks later i.e. after the mediation phase. In addition, to trace the effects of the mediation on the listening ability of the learners especially their understanding of conversational imlplicatures, the independent performance of both the experimental and control group on the 7 LTTs of the mediation phase was also analyzed. The mean scores of the pretest, posttest, and the 7 LTTs along with their standard deviations and the number of participants in each group are presented in Table 1.

Table 1

Descriptive statistics of the pretest, posttest, and the 7 LTTS

\begin{tabular}{lcccc}
\hline \multicolumn{1}{c}{ Test Type } & \multicolumn{2}{c}{ Experimental group $(n=24)$} & \multicolumn{2}{c}{ Control group $(n=26)$} \\
\hline & Mean & $S D$ & Mean & $S D$ \\
Pretest & 36.00 & 1.72 & 36.08 & 1.92 \\
LTT1 & 1.58 & 0.83 & 1.54 & 0.76 \\
LTT2 & 2.29 & 0.96 & 1.47 & 0.44 \\
LTT3 & 2.71 & 0.80 & 1.20 & 0.56 \\
LTT4 & 2.81 & 0.68 & 1.41 & 0.46 \\
LTT5 & 2.86 & 0.93 & 1.25 & 0.61 \\
LTT6 & 3.00 & 0.88 & 1.31 & 0.67 \\
LTT7 & 3.50 & 1.10 & 1.31 & 0.61 \\
Posttest & 44.83 & 3.56 & 36.35 & 1.72 \\
\hline
\end{tabular}

Note. Pretest and posttest maximum possible score $=50$; LTT maximum possible score $=5$

In order to determine that both the experimental and control groups were at the same level of listening ability at the outset of this study an independent samples t-test was run between the pretest scores of them. To find the effect of receiving mediation on the experimental group, paired t-tests were run between the pretest and posttest scores of the experimental group and the control group. Moreover, an independent samples t-test was run between the posttest scores of both groups (Table 2).

Table 2

Comparison tests between the experimental and control groups on the pretest and posttest

\begin{tabular}{lcc}
\hline & $t$ & $p$ \\
\hline Pretest exp. $\times$ pretest cont. & -0.15 & 0.88 \\
Pretest exp. $\times$ posttest exp. & -16.76 & 0.00 \\
Pretest cont. $\times$ posttest cont. & -1.57 & 0.13 \\
Posttest exp. $\times$ posttest cont. & 10.87 & 0.00 \\
\hline
\end{tabular}

The results showed that at the outset of the tests there were no significant difference in the listening comprehension ability of the both groups $(\mathrm{t}(48)=-0.15, p>0.05)$. Moreover, the mediation caused the experimental group to outperform the control group in the posttest (Pretest exp. $\times$ posttest exp. $\mathrm{t}(23)=-16.76$, $p<0.05$; Pretest cont. $\times$ posttest cont. $\mathrm{t}(25)=-1.57, p>0.05$; and Posttest exp. $\times$ posttest cont., $\mathrm{t}(48)=10.87$, $p<0.05)$.

The comparison of the performance of the experimental group and the control group on the seven listening test tasks (LTT) also attested the benefit of the G-DA procedure in promoting the listening ability of the participants especially their pragmatic understanding (Table 3 ). 
Table 3

Comparison tests between the experimental and control groups on the 7 LTTs

\begin{tabular}{lcc}
\hline & $t$ & $p$ \\
\hline LTT1 exp. $\times$ LTT1 cont. & 1.20 & 0.04 \\
LTT2 exp. $\times$ LTT2 cont. & 2.97 & 0.00 \\
LTT3 exp. $\times$ LTT3 cont. & 7.69 & 0.00 \\
LTT4 exp. $\times$ LTT4 cont. & 8.42 & 0.00 \\
LTT5 exp. $\times$ LTT5 cont. & 7.14 & 0.00 \\
LTT6 exp. $\times$ LTT6 cont. & 7.62 & 0.00 \\
LTT7 exp. $\times$ LTT7 cont. & 8.57 & 0.00 \\
\hline
\end{tabular}

As it is apparent in this table, the results of independent t-tests, show there was a significant difference in the performance of the experimental and control groups on LTT1 through LTT7 ( $p<0.05$ in all). This means receiving mediation has been effective for the experimental group and resulted in enhancing their listening comprehension ability since only the experimental group received mediation during the G-DA procedure.

\subsection{Qualitative data analysis}

The second research question aimed to discover what type mediational strategies during G-DA pedagogical intervention can best raise the pragmatic understanding of the conversational implicatures of the L2 listeners. To answer this question, the mediator-learners interactions of every mediation session were analyzed to detect signs of development of pragmatic understanding. From the analyses emerged the following typology of mediations which were effective in raising the pragmatic comprehension of the learners in their listening comprehension ability.

Mediation Typology - As it was mentioned before, this study implemented an interactionist G-DA approach; thus, the mediation offered to learners was not pre-specified and emerged from the mediator's ongoing collaborations with learners. This type of flexible and fine-tuned mediation is assumed to be more effective in bringing about learning than standardized mediation (Vygotsky, 1998). The analysis of interactions, thus, led to the detection of nine meditational strategies which, following Aljaafreh and Lantolf (1994), are arranged from the most implicit to the most explicit (see Figure 1).

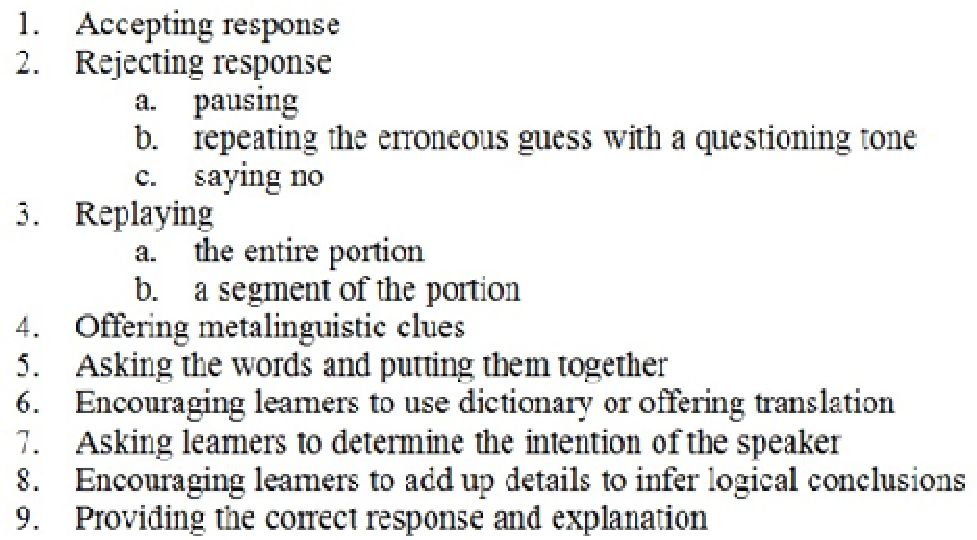

Figure 1. Typology of mediational strategies

Analysis of the mediational strategies in mediator-leaners G-DA interactions - In this part three excerpts of the G-DA interactions between the mediator and the learners are analyzed to show the function of the nine mediational strategies detected in this study.

Excerpt 1 depicts how the mediational strategies of accepting response, rejecting response, replaying, and 
offering metalinguistic cues are used to facilitate the comprehension. Before demonstrating how these four strategies work in excerpt 1 , they will be briefly explained here. The most implicit strategy on the above-mentioned list is the accepting response move. This strategy was used by the mediator to clear the doubts of a learner when she was uncertain about the correctness or appropriateness of her response. This mediational strategy accompanied with the encouragement provided to the learners reflects Vygotsky's affective-volitional aspect of learning (Warford, 2010) which prescribes offering caring support to instill confidence in the students (Mahn \& John-Steiner, 2002). The less experienced students with the help of this strategy can become aware of their equally important roles as questioners seeking clarification, which can lead to the building of their confidence and at the same time helps promote their learning (Wells, 1999).

The second strategy on the list is the rejecting response which includes three sub-strategies: 1) pausing; 2) repeating the erroneous guess with a questioning tone; and 3) saying no. The support given moves from most implicit to most explicit which is offered depending upon the learners' responsiveness. This strategy sends a clear message to the students that something is amiss with their performance encouraging them to work through the difficulty. It also has the function of encouraging other students to take part in the interaction and attempt their recall.

Upon noticing learners' failure in providing recall or giving a correct response, the mediator applied the replaying strategy. Research has revealed that multiple exposures to a listening text generally aid its comprehension (Field, 2002; Elkhafaifi, 2008). This mediational strategy consists of two sub-strategies: 1) listening to the entire portion, and 2) listening to a segment from the portion, the latter being more explicit than the former in that it provides more assistance by narrowing the learners' focus to the part, where they had some misunderstandings. By offering the learners a chance to listen to the portion in question more than once, this strategy provides them with an opportunity to attempt to notice the aspects they have failed to catch during the first listening.

The fourth mediational strategy on the list concerns offering metalinguistic cues to bring the attention of the learners to the structure and function of language. Metalinguistic knowledge is defined as the explicit and verbalizable knowledge about the syntactic (including the subject, verb, object, noun, adjective, etc.) and semantic (including collocations, idioms, etc.) features of an L2 (Hu, 2002). Raising metalinguistic awareness is found to be beneficial for the students' L2 comprehension. This strategy was implemented by providing metalinguistic clues which included comments, information and questions related to the structure and function of language without explicitly providing the correct form (Lyster \& Ranta, 1997). The excerpt below taken from LTT3 captures the mediating role of the above-mentioned strategies:

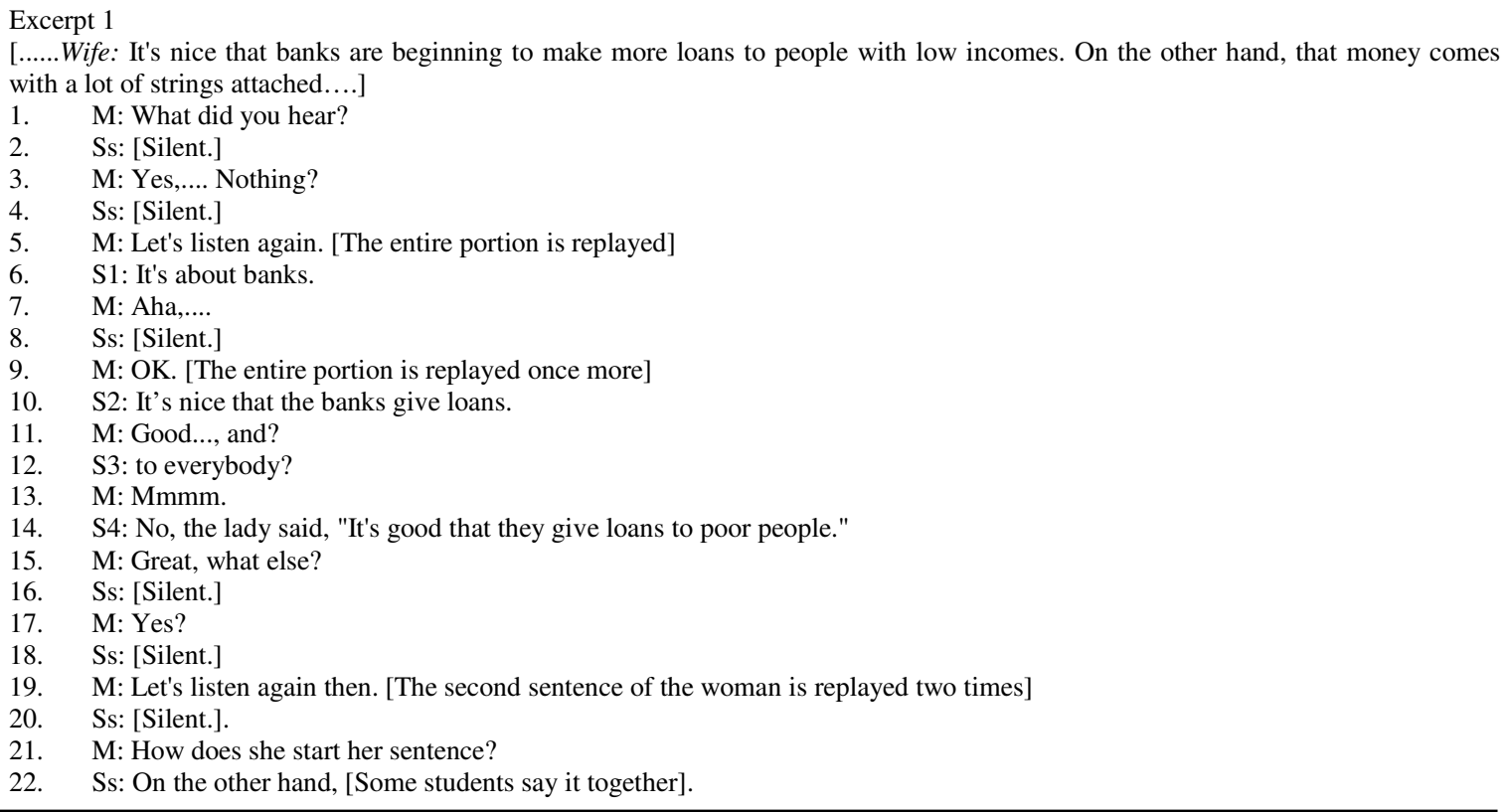


23. M: When do we use 'on the other hand', 'in contrast', 'on the contrary'....?

24. S6: When we want to say something opposite, something bad.

25. M: Very good. Now, let's listen once more. [The second sentence of the woman is replayed.]

26. S7: She says that money has a lot of strings.

27. M: That money has a lot of strings?

28. S8: No, the lady says but that money comes with a lot of strings attached.

29. M: Very good, but what does "a lot of strings attached" mean?

30. S4: Banks use strings to tie money. [Showing with her hands that she is tying something]

31. M: No, it's not that. Anything else?

32. Ss: [Silent.]

33. M: OK. Check it in your dictionaries.

This interaction demonstrates that the learners were not able to recall the content of the portion heard after the first hearing. However, after the second replay of the entire portion, S1 attempted a correct partial recall (line6) which, after the third replay was completed to some extent by S2's contribution (line10). The delayed recalls of these two students indicated that the mediator's use of the sub-strategy of replaying the entire portion helped them to regulate their thoughts and removed uncertain conjectures they had cultivated in their previous listenings. The Mediator's pausing, a sub-strategy of rejecting response, in line13 encouraged S4 to make an attempt to overcome the difficulty and to provide a complete recall of the sentence heard.

However, as it evident in lines16 and 18, the sub-strategy of replaying the entire portion was not sufficient for the learners to provide an acceptable recall. The mediator, therefore, decided to narrow down the scope of the focus and played only the segment that was supposedly hindering the students' understanding of the text (line19). With applying this sub-strategy, i.e. listening to a segment from the portion, the mediator gave further assistance to the learners by directing the learners' attention only to the problem area. Nevertheless, facing with the silence of students (line20), the mediator realized this sub-strategy was also inefficient. Therefore, she provided a more explicit mediational support and asked them to pay attention to the beginning of the sentence, narrowing their focus to a specific word. She helped them collect their attentional resources to focus on the cohesive device "on the other hand" and asked them what semantic relation it would produce between the two idea units that it connected, i.e. using the strategy of offering a metalingustic cue (lines21 and 23). This mediation aided them to better assemble the portions they had decoded. Upon realizing this, the mediator decided to use a less explicit mediational move and replayed the segment the learners could not recall. After hearing the segment once more, one of the students had an incorrect recall. The mediator's repeating of the erroneous guess with a questioning tone (the strategy of rejecting response) in line 27 encouraged S8 to recite what was said only verbatim in line 28. This mediational strategy led the learners to correctly process this idiom phonologically but not semantically since it was absent in their lexicon repertoire. The rejection strategy in line31 did not have a positive outcome indicating its inefficiency, and that the learners needed a different type of support.

Throughout this interaction, the accepting response mediational move was observed a number of times in lines 7,11,15, 25, and 29 which had the function of ascertaining learners of the appropriateness of their comprehension and encouraging the less participating and silent students to take part in the interactions. The complimentary feedbacks of the mediator like 'good', 'great', etc. served as energizing motivators for instilling the confidence learners needed in sustaining and furthering the cooperation.

Excerpt 2 shows how the fifth strategy on the list, asking the words and putting them together, operates. This strategy was implemented when the mediator observed learners were not able to produce even a partial recall after multiple exposures to the entire portion or parts of it, which was possibly due to the semantic density or syntactical complexity of the sentence. Through division of labor among learners, this strategy encourages them to take part in a joint intellectual activity and work cooperatively to carry out activities that no single group member could do individually. It supports the principle that purposeful group work results in sharing of knowledge and abilities which moves the group forward in its ZPD while also benefitting individuals (Petrovsky, 1985). Therefore, in order to implement this strategy the mediator asked the students to verbalize the words they remembered from their listening to the sentence, put them together and try to make sense of them, an action which activates their top-down and bottom-up listening processes. The excerpt below, taken from LTT4, shows how this mediational move encouraged collaborative work. 
Excerpt 2 [......the equity of creativity can be stifled by a particular context or environment.....] ........lines deleted.....

1. M: What words did you hear?

2. S1: Creativity

S2: Environment

M: Great, what is the verb of the sentence? Let's hear the verb. [The sentence is replayed]

S3: rifle

$\mathrm{M}$ : rifle?

S4: No, it was stifle.

M: What does it mean?

S4: To stop something from happening.

M: Perfect, but what stifled what? What other words did you hear?

Ss: [Silent.]

M: OK, let's listen again then. [The sentence is replayed]

S5: The verb is "can be stifled"; it's passive.

M: Very good, what other words did you hear?

S6: equity of creativity, a particular context

Ss: [Silent.].

M: Good. Now, who can tell us what can be stifled and by what?

S1: the equity of creativity can be stifled by a particular context

M: And..?

S6: and by the environment

M: That's it.

The interaction above demonstrates the mediator intervened in line7 and tried to lower the comprehension load by breaking down the entire sentence into manageable portions. To this end, she elicited the words some students had picked up on their own and put them at the disposal of other members of the class (lines8, 9, 13, and 21). Then to help the students benefit from one another's contribution, she encouraged the learners to re-attempt their recall collaboratively (line23). Through such joint cooperation, S1 who had earlier provided only a partial segment put together the decoded words and uttered most of the content (line24) which then S6 completed her utterance. This contribution proves that during G-DA interactions, secondary interactants may simultaneously benefit from mediation offered to a primary interactant (Lantolf \& Yáñez-Prieto, 2003; Poehner, 2009). Moreover, this observation confirms the role of G-DA interactions in creating a situation for the learners to recognize the interdependence of their goals resulting in pooling their mental efforts in order to overcome difficulties (Petrovsky, 1985; Poehner, 2009).

Excerpt 3 reveals how the mediator makes use of the mediational strategies of using dictionary or offering translation, determining the real intention of the speaker, adding up details to infer logical conclusions and providing the correct response and explanation to diagnose the sources of difficulties learners encounter in comprehending implied meanings in L2 listening texts and to promote their understanding. After a brief description of each strategy, excerpt 3 will be analyzed. The strategy of using dictionary or offering translation was used when the mediator observed a lexical item was unknown to the learners, and implementation of other mediational strategies was futile to infer the meaning of that lexical item. The function of this strategy was twofold: 1) teaching learners effective dictionary-use skills, 2) checking the meaning of a totally new item. Dictionary use served as one of the symbolic artifacts the mediator applied throughout her engagement with the learners which she assumed could trigger the learning process of the learners and might bring about the expansion of their ZPDs. The notion which has already been stressed by Vygotsky (1978) emphasizing that higher forms of thinking are socially and culturally derived, which is assumed to emerge as a consequence of our interactions with other individuals and with physical and symbolic artifacts.

Since all of the LTTs used during the mediation phase had a number of conversational implicatures in which the speakers' words had additional conveyed meanings or some implied meanings, the mediator had to encourage learners to extract meaning beyond the literal meaning of words and sentences (Thomas, 1995). One strategy that the mediator used was to draw the attention of the learners to determine the real intention of the speaker, the seventh strategy on the list. This strategy was implemented when the mediator ascertained that the learners did not have any problems in the literal meaning or grammatical complexity of what was heard in the listening text. This mediation move usually began with the questions "Did the speaker really mean what he/she said?" and "What did he/she really mean by saying ....?" 
The mediator used the strategy of adding up details to infer logical conclusions, the eighth strategy, to enlighten the learners that the intended message of a speaker is not always said clearly. Thus, she encouraged the learners to hunt down clues, whether linguistic or extralingistic (Buck, 2001; Nunan, 2002; Vandergrift, 2004), put them together in order to find a logical conclusion that had not been expressed in words. This strategy fosters the collaborative sharing of knowledge and abilities of the learners which is assumed to have a great impact on improving the learners' pragmatic understanding as well as moving the group forward in its ZPD.

The last and most explicit mediational move on the list is the strategy of providing correct response and explanation which reflects the instructional function of G-DA. According to Vygotsky (1978), the driving motor of intellectual development is providing instruction, and when the instruction given is sensitive to learners abilities, it can help them move up to a higher level of ZPD, which in turn triggers internal processes of development. This mediational strategy was offered when the mediator realized the inefficiency of the other mediational strategies in guiding the learners to decode the implicit message of the text heard. This lack of understanding reflected the incompetency of pragmatic comprehension of the learners which could be due to a lack of the background information or insufficient inferential skills on the part of the learners. To resolve this deficiency in the learners' comprehension, the mediator described the unknown meaning by comparing it to an experience common to them. Then she explained to the learners how to make use of details and the factual information they heard and to combine them with their own background knowledge and experiences to infer hidden meanings. The employment of these four strategies was detected in the following excerpt taken from LTT2:

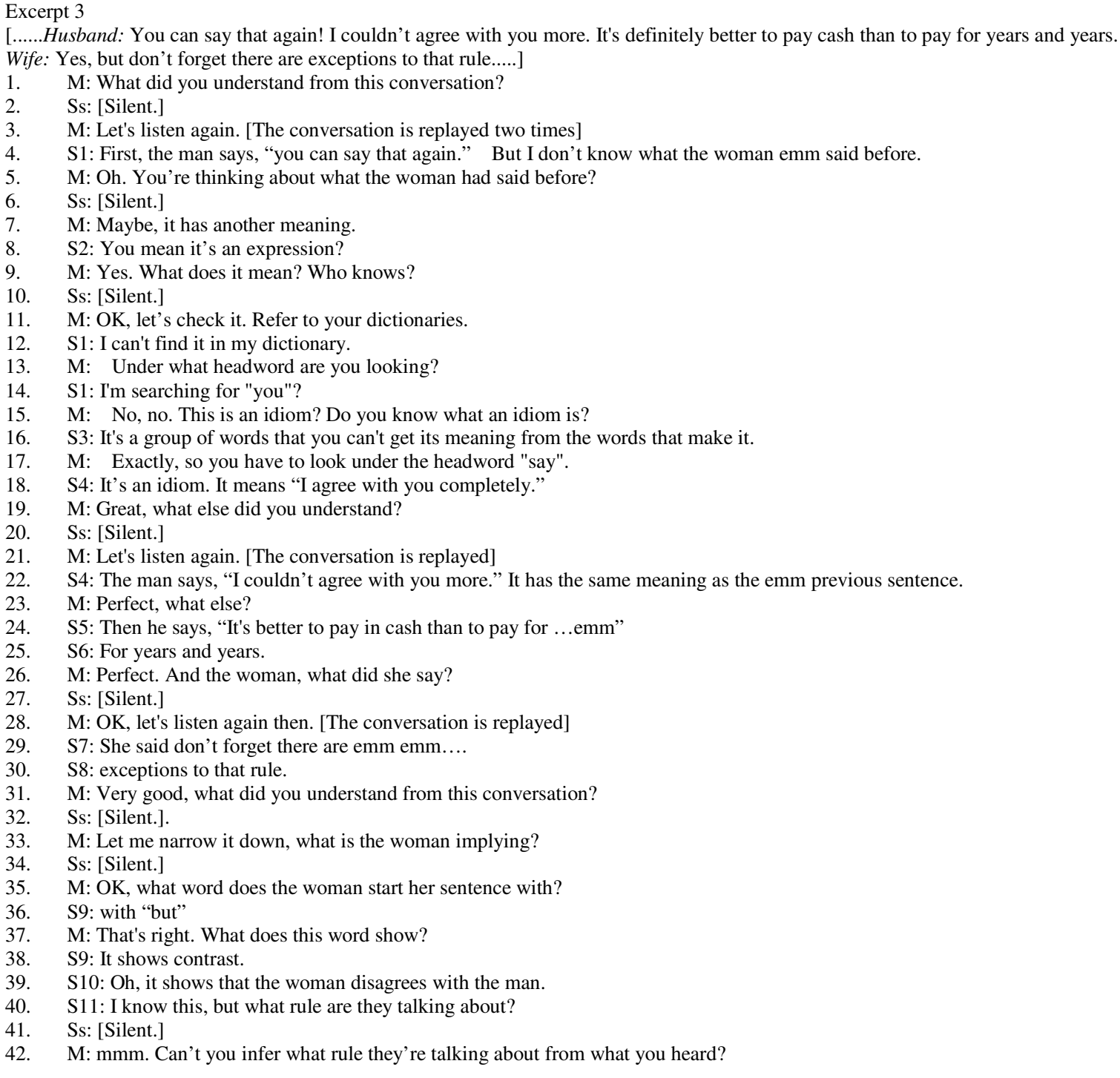


43. Ss: [Silent.]

44. M: OK, as you remember the man said, "It's definitely better to pay cash than to pay for years and years." What do we pay back little by little and usually for years?

45. S11: a loan?

46. M: Yes, so the rule refers buying something in cash and not getting a loan. Is it always possible to buy something cash?

47. S12: No sometimes something is very expensive, like buying a house.

48. M: Exactly. So, the woman is implying in her speech the man has to think through what she had said and not agree with her without thinking. Sometimes you cannot save enough money to buy something cash, and you do not have any other choice than getting a loan.

During this interaction the strategies of accepting response, rejecting response and replaying, the most implicit strategies, were used several times; however, the learners' inability to provide a correct recall indicated a more explicit prompt was required. Line4 shows the idiom "you can say that again" is absent in the lexical repertoire of the learners since by multiple exposures to this sentence, they have only arrived at the literal meaning of the combination of words heard, oblivious of its figurative meaning. The mediator, therefore, implemented the strategy of dictionary use (line11) and provided a dictionary-use skill on how to find idioms in dictionaries (lines15 and 17). Following the teacher's mediation, one of the students looked up the idiom in her dictionary and informed the class of its meaning (line18). Upon realizing that the learners were not cognizant of the hidden intention of the speaker, in line33 the mediator implemented the strategy of determining the real intention of the speaker to help learners discover what the speaker was saying beyond her words. This strategy, however, was not sufficient to elicit a correct response from the learners. The mediator, thus, attempted to make use of the strategy of adding up details to infer logical conclusions (line42). Nevertheless, she was finally faced with the learners' inability to grasp the intended meaning which indicated that the required skills for making an understanding of this implied meaning were beyond their ZPD. The mediator, thus, decided to explicitly provide the class with the correct response, and through lines 44,46 and 48 she clearly explained to the learners how to arrive at the speaker's implicit intent by activating the learner's background knowledge.

\section{Discussions and Conclusions}

This paper provided a quantitative and a qualitative account of the results in order to answer the research questions posed. The first research question concerned the applicability of G-DA to assess and enhance listening comprehension ability especially the pragmatic understanding of conversational implicatures among intermediate EFL learners. The analyses of the quantitative data provided by the pretest, posttest and the 7LTTs indicated that, over time, mediation sensitive to the learners ZPD resulted in significant changes in their listening comprehension ability improving their pragmatic understanding of conversational implicatures. This accords to the developmental theory upon which dynamic assessment is based which asserts that any mediational strategy that is attuned to the learners' ZPD can simultaneously bring to the surface those abilities that have matured along with those which are on the verge of maturing enabling the mediator to provide opportunities for the maturation of new abilities (Sternberg \& Grigorenko, 2002; Haywood \& Lidz, 2007). The effectiveness of G-DA procedures in diagnosing and promoting pragmatic knowledge found in this study runs in accordance with the previous attempts revealing the benefits of instruction in pragmatic development in both production and comprehension (Bardovi-Harlig, 2011; Bardovi-Harlig \& Nickels, 2011; Murray 2011; and Taguchi, 2005).

The data obtained from the pretest and posttest of the experimental group showed that although the learners of this group received a significant gain from the G-DA intervention, the standard deviation of the posttest exhibited considerable variation, an indication that some learners were improving more, and some less than others. This noticeable variation in standard deviation was also observable in the means the experimental group gained from the 7 LTTS taken during the mediation phase when compared to the standard deviation of the means of the control group on these tests who did not receive any mediation at all. A finding which is in line with Ableeva and Lantolf (2011), Kozulin and Garb (2002), and Poehner and Lantolf (2013) signifying that the learners were not developmentally at the same ability level, considering that some responded more favorably to mediation than others.

The qualitative examination of the transcripts of mediator-learners G-DA interactions also attested the 
effectiveness of providing mediation in the development of learners' listening comprehension. Moreover, it revealed learners had both regression and progression in their responses to mediation. However, it was observed that through the final sessions of the mediation phase, the progressive moves outweighed the regressive ones which is an indication of development. This observation conforms to Vygotsky's idea of development of psychological abilities in that it "includes not just evolutionary but also revolutionary changes, regressions, gaps, zigzags, and conflicts" (Vygotsky, 1997, p. 221). This discovery aligns with the findings of Ableeva (2010), Ableeva and Lantolf (2011), Aljaafreh and Lantolf (1994) and Poehner (2008) that the development of listening ability similar to the development of any mental system is not a smooth and steady process. In addition, it was spotted that toward the final sessions of mediation learners needed very few explicit mediational strategies and demanded implicit mediation. This indicates that the learners' performance is moving from other regulation to self-regulation; in other words, the zone of proximal development of the learners was transforming to the zone of actual development.

The second research question intended to discover the mediational strategies that could nurture the pragmatic understanding of the conversational implicatures of the L2 listeners. The qualitative and grounded analyses of the mediator-learners interactions during the mediation phase of this study led to the detection of nine types of mediational strategies. The strategies arranged from the most implicit to the most explicit, are as follows: 1) Accepting response; 2) Rejecting response consisting of (a) pausing, (b) repeating the erroneous guess with a questioning tone, and (c) saying no; 3) Replaying including (a) replaying the entire portion, and (b) replaying a segment of the portion; 4) Asking the words and putting them together; 5) Offering metalinguistic clues; 6) Asking learners to use dictionary or offering translation; 7) Asking learners to determine the real intention of the speaker; 8) Encouraging learners to add up details to infer logical conclusions; and 9) Providing the correct response and explanation.

The typology of mediational strategies developed in this study is to some extent similar to the one reported in Ableeva (2010) in which one-to-one (teacher-learner) DA procedures outside the classroom were used to assess and promote listening; however, a number of discrepancies are seen between them. This disagreement could be due to the difference in the procedures and the listening texts used in these two studies. Ableeva's typology emerged from the analysis of a dyadic model with one teacher and one student, tailoring the mediation to only one ZPD. However the typology developed in this study resulted from the mediator's interactions with a group of learners in the classroom setting, interacting with a group of ZPDs. Moreover, Ableeva used authentic speech of native speakers without pointing whether any implicatures were within these aural texts, whereas the listening texts used in this study had implied meanings aimed at assessing learners' pragmatic knowledge.

A mediational move which was absent in Ableeva's typology was the strategy of asking words and putting them together which allowed for a group of learners to collaboratively construct new understandings of the object of study. The mediator's intention in providing such strategy was to break down the task into manageable portions and to encourage all learners whether more skilled or less skilled to work cooperatively and pool their knowledge to carry out activities that no single group member could do independently. This strategy aimed to materialize Petrovsky's (1985, p. 183) concept of "joint intellectual activity" and "the pooling of mental efforts" to overcome difficulties in the social context of the classroom. In addition, this strategy was effective in changing the class activity into a "group-as-collective" in which all group members were united in working toward a common goal (Petrovsky, 1985, p. 191).

The strategies of a) Asking learners to determine the real intention of the speaker, and b) Encouraging learners to add up details to infer logical conclusions were also absent in Ableeva's typology. These two mediational moves were provided by the mediator in order to promote the pragmatic comprehension of the learners. The first strategy was offered to remind learners that the understanding the real intent of the speakers depends not only on structural and linguistic knowledge (e.g., grammar, lexicon, etc.) of the speaker and listener, but also on the situation of the utterance, any pre-existing knowledge about those involved, and other factors (Thomas, 1995). The purpose of the second strategy was twofold. One purpose was to encourage learners to take 
note of bits of information grasped whether linguistic or extralinguistic (e.g. tone of voice, speaker's goals and attitudes toward a subject) and combine them with their previous personal experiences and world knowledge in order to infer a logical meaning of the text heard. In the literature on listening comprehension, extralinguistic reminders in resolving listening problems have proved to be beneficial (e.g. Buck, 2001; Nunan, 2002; Vandergrift, 2004). The other purpose of this strategy was to engage them in a purposeful activity toward a common goal and to foster a sense of collaboration among them since it is the sharing of knowledge and abilities that is assumed to move the group forward in its ZPD while also benefiting every single group member (Petrovsky, 1985; Poehner, 2009).

The analysis of the G-DA interactions showed by applying these mediational strategies in the mediation phase and based on the responsiveness of the learners to each mediating move, the mediator could gain insights into the developmental changes and sources of difficulties the learners had in their comprehension of conversational implicatures. The impediments hampering the pragmatic understanding of the learners in the listening texts found in this study were lack of lexical knowledge of the L2 especially the L2 idiomatic expressions, limited knowledge of the L2 culture, and inferencing skills. The mediator attempted to redress this lack of knowledge in the learners by offering appropriate forms of mediation in the ZPD of the learners which to some extent led to the development of the pragmatic understanding of the learners in their listening comprehension ability.

The findings of this study can have some implications for second language pedagogy. The G-DA procedures used in the present study have the potential to inform EFL listening comprehension pedagogy. ZPD-oriented listening courses with a focus on raising L2 pragmatic awareness can be designed since G-DA interactions were observed in this study to bring about a better understanding of L2 pragmatics in listening comprehension on the part of the learners. Moreover, ZPD-oriented pragmatic teaching courses could be designed to raise learners' L2 pragmatic knowledge to help learners become familiar with the range of pragmatic devices and practices in the target language. With such instruction, learners can learn to expand their perception of the target language and those who speak it. In addition, the findings of this study can contribute to a deeper understanding of how to use Vygotksy's ZPD construct to guide interaction within the classroom context.

Finally, it is important to note that the substantial results of this study must be interpreted within particular study limitations. The number and type of mediational strategies detected in this study are recommended only for the intermediate learners of this study in the context of the language institute which was implemented. More rigorous studies of this kind are needed which then might lead to the development of an inventory of mediational strategies applicable to all L2 intermediate learners. Although the sample size was small for both qualitative and quantitative data, the results of this study can induce some insight concerning the teachability of pragmatic awareness and how DA may be organized to function within a class's ZPD.

\section{References}

Abdolrezapour, P., Tavakoli, M., \& Ketabi, S. (2014). Qualitative analysis of mediational strategies in emotionalized dynamic assessment of L2 reading comprehension, International Journal of Research Studies in Language Learning, 1(3), 51-66.

Ableeva, R. (2010). Dynamic Assessment of listening comprehension in second language learning. Unpublished doctoral dissertation, The Pennsylvania State University, University Park, PA.

Ableeva, R., \& Lantolf, J. P. (2011). Mediated dialogue and the microgenesis of second language listening comprehension. Assessment in Education: Principles, Policy \& Practice, 18(2), 133-149. http://dx.doi.org/10.1080/0969594X.2011.555330

Aljaafreh, A., \& Lantolf, J. P. (1994). Negative feedback as regulation and second language learning in the zone of proximal development. The Modern Language Journal, 78(4), 465-483. http://dx.doi.org/10.1111/j.1540-4781.1994.tb02064.x

Antón, M. (2009). Dynamic assessment of advanced second language learners. Foreign Language Annals, 42(3), 
Group dynamic assessment of EFL listening comprehension: Conversational implicatures in focus

576-598. http://dx.doi.org/10.1111/j.1944-9720.2009.01030.x

Bardovi-Harlig, K. (2011). Assessing familiarity with pragmatic formulas: Planning oral/aural assessment. In N. R. Houck \& D. H. Tatsukik (Eds.), Pragmatics: Teaching natural conversation (pp. 7-22). New York: TESOL.

Bardovi-Harlig, K., \& Dörnyei, Z. (1998). Do language learners recognize pragmatic violations? Pragmatic versus grammatical awareness in instructed L2 learning. TESOL Quarterly, 32, 233-259. http://dx.doi.org/10.2307/3587583

Bardovi-Harlig, K., \& Mahan-Taylor, R. (2003). Teaching pragmatics. Washington, DC: United States Department of State.

Bardovi-Harlig, K., \& Nickels, E. L. (2011). No thanks, I'm full: Raising awareness of expressions of gratitude and formulaic language. In N. R. Houck \& D. H. Tatsuki (Eds.), Pragmatics: Teaching natural conversation (pp. 23-40). New York: TESOL.

Blight, R. (2002). Classroom procedure for explicit instruction in conversational implicature. The Japan Association for Language Teaching conference proceedings.

Bloomfield, A., Wayland, S. C., Rhoades, E., Blodgett, A., Linck, J., \& Ross, S. (2011). What makes listening difficult? Factors affecting second language listening comprehension. (Technical Report TTO 81434 E.3.1). College Park, MD: University of Maryland Center for Advanced Study of Language.

Bouton, L. F. (1999). Developing non-native speaker skills in interpreting conversational implicatures in English: Explicit teaching can ease the process. In E. Hinkel (Ed.): Culture in second language teaching and learning (pp. 47-70). New York, NY: Cambridge University Press.

Buck, G., (2001). Assessing listening. Cambridge: Cambridge University Press. http://dx.doi.org/10.1017/CBO9780511732959

Budoff, M. (1987). The validity of learning potential assessment. In C.S. Lidz (Ed.), Dynamic assessment: An interactive approach to evaluating learning potential (pp. 52-81). New York: Guilford.

Davin, K. J. (2013). Integration of dynamic assessment and instructional conversations to promote development and improve assessment in the language classroom, Language Teaching Research, 17(3), 303-322. http://dx.doi.org/10.1177/1362168813482934

Elkhafaifi, H. (2008). The effect of prelistening activities on listening comprehension in Arabic learners. Foreign Language Annals, 38, 505 - 513. http://dx.doi.org/10.1111/j.1944-9720.2005.tb02517.x

Feuerstein, R., Rand, Y., Hoffman, M. B., \& Miller, R. (1980). Instrumental enrichment. Baltimore, MD: University Park Press.

Field, J. (2002). The changing face of listening. In J. C. Richards \& W. A. Renandya, (Eds.). Methodology in language teaching: An anthology of current practice (pp. 242-247). Cambridge: Cambridge University Press. http://dx.doi.org/10.1017/CBO9780511667190.033

Geranpayeh, A. (2003). A quick review of the English Quick Placement Test, Research Notes Quarterly, 12, 8-10.

Gibbons, P. (2003). Mediating language learning: Teacher interactions with ESL students in a content-based classroom. TESOL Quarterly, 37, 247-273. http://dx.doi.org/10.2307/3588504

Graham, S. (2006). Listening comprehension: The learners' perspective. System, 34, 165-182. http://dx.doi.org/10.1016/j.system.2005.11.001

Grice, P. (1975). Logic and conversation. In P. Cole \& J. L. Morgan (Eds.), Syntax and semantics (Speech acts) (pp. 41-58). New York, NY: Academic Press.

Haywood, H. C., \& Lidz, C. S. (2007). Dynamic assessment in practice: Clinical and educational applications. Cambridge: Cambridge University Press.

Hidri, S. (2014). Developing and evaluating a dynamic assessment of listening comprehension in an EFL context. Language Testing in Asia, 4(4). http://dx.doi.org/10.1186/2229-0443-4-4

Hu, H. (2002). Psychological constraints on the utility of metalinguistic knowledge in second language production. Studies in Second Language Acquisition, 24(3), 347-386. http://dx.doi.org/10.1017/S0272263102003017

Kasper, G., \& Schmidt, R. (1996). Developmental issues in interlanguage pragmatics. Studies in Second 
Hashemi Shahraki, S., Ketabi, S., \& Barati, H.

Language Acquisition, 18, 149-169. http://dx.doi.org/10.1017/S0272263100014868

Kozulin, A., \& Garb, E. (2002). Dynamic assessment of EFL text comprehension. School Psychology International, 23(1), 112-127. http://dx.doi.org/10.1177/0143034302023001733

Kubota, M. (1995). Teachability of conversational implicatures to Japanese EFL learners. The Institute for Research in Language Teaching Bulletin, 5, 35-67.

Lantolf, J. P., \& Poehner, M. (2011). Dynamic assessment in the classroom: Vygotskian praxis for L2 development. Language Teaching Research, 15(11), 11-33. http://dx.doi.org/10.1177/1362168810383328

Lantolf, J. P., \& Yáñez-Prieto, M. C. (2003). Talking yourself into Spanish: The role of private speech in second language learning. Hispania, 86, 98-110. http://dx.doi.org/10.2307/20062818

Lyster, R., \& Ranta, L. (1997). Corrective feedback and learner uptake: Negotiation of form in communicative classrooms. Studies in Second Language Acquisition. 20, 37-66.

Mackey, A., \& Gass, S. (2005). Second language research methodology and design. Mahwah, NJ: Lawrence Erlbaum Associates.

Mahn, H., \& John-Steiner, V. (2002). The gift of confidence: A Vygotskian view of Emotions in G. Wells \& G. Claxton (Eds.) Learning for Life in the 21st Century: Sociocultural Perspectives on the Future of Education. Blackwell Publishing Ltd. http://dx.doi.org/10.1002/9780470753545.ch4

Murray, J. C. (2011). Do bears fly? Revisiting conversational implicature in instructional pragmatics. TESL-EJ 15(2). Retrieved from http://www.tesl-ej.org/wordpress/issues/volume15/ej58/ej58a4/

Nunan, D. (2002). Listening in language learning. In J. C. Richards \& W. A. Renandya, (Eds.). Methodology in language teaching: An anthology of current practice (pp. 238-241). Cambridge: Cambridge University Press. http://dx.doi.org/10.1017/CBO9780511667190.032

Petrovsky, A. V. (1985). Studies in psychology: The collective and the Individual. Moscow: Progress.

Poehner, M. E. (2008). Dynamic assessment. A Vygotskian approach to understanding and promoting L2 development. Berlin: Springer. http://dx.doi.org/10.1007/978-0-387-75775-9

Poehner, M. E. (2009). Group dynamic assessment: Mediation for the L2 classroom. TESOL Quarterly, 43, 471-491.

Poehner, M. E., \& Lantolf. J. P. (2005). Dynamic Assessment in the language classroom. Language Teaching Research, 9(3), 233-265. http://dx.doi.org/10.1191/13621688051r166oa

Poehner, M. E., \& Lantolf. J. P. (2013). Bringing the ZPD into the equation: Capturing L2 development during computerized dynamic assessment (C-DA) Language Teaching Research, 17(3), 323-342. http://dx.doi.org/10.1177/1362168813482935

Révész, A., \& Brunfaut, T. (2013). Text characteristics of task input and difficulty in second language listening comprehension. Studies in Second Language Acquisition, 35, 31- 65. http://dx.doi.org/10.1017/S0272263112000678

Roever, C. (2006). Validation of a web-based test of ESL pragmalinguistics. Language Testing, 23(2), 229-256. http://dx.doi.org/10.1191/02655322061t329oa

Rose, K. R., \& Kasper, G. (2001). Pragmatics in language teaching. Cambridge: Cambridge University Press. http://dx.doi.org/10.1017/CBO9781139524797

Sternberg, R. J., \& Grigorenko, E. L. (2002). Dynamic Testing. New York: Cambridge University Press.

Taguchi, N. (2005). Comprehending Implied Meaning in English as a Foreign Language. The Modern Language Journal, 89(4), 543-562. http://dx.doi.org/10.1111/j.1540-4781.2005.00329.x

Tavakoli, M., Hashemi Shahraki, S., \& Rezazadeh, M. (2012). The Relationship between Metacognitive Awareness and EFL Listening Performance: Focusing on IELTS Higher and Lower Scorers. The Journal of Language Teaching and Learning, 2, 24-37.

Thomas, J. (1995). Meaning in Interaction: An Introduction to Pragmatics. London: Longman.

Vandergrift, L., \& Goh, C. ( 2009 ). Teaching and testing listening comprehension. In M. Long \& C. Doughty (Eds.), The handbook of language teaching (pp. 395 - 411). Oxford: Blackwell. http://dx.doi.org/10.1002/9781444315783.ch22

Vandergrift, L. (2004). Learning to listen or listening to learn. Annual Review of Applied Linguistics, 24, 3-25. 
http://dx.doi.org/10.1017/S0267190504000017

Vygotsky, L. (1978). Mind in society: The development of higher psychological processes. M. Cole, V.

John-Steiner, S. Scribner \& E. Souberman, (Eds. and Trans.) Cambridge, MA: Harvard University Press. (Original work published in 1955).

Vygotsky, L. S. (1997). The History of the development of higher mental functions. In R. W. Rieber (Ed.), The collected works of L. S. Vygotsky: The history of the development of higher mental functions (Vol. 4, pp. 1-26). New York: Plenum.

Vygotsky, L. S. (1998). The problem of age. In R. W. Rieber (Ed.). Child psychology, Vol. 5.Collected works of L. S. Vygotsky (pp. 187- 205). New York: Plenum. (Original work published 1932-1934).

Warford, M. K. (2010). The zone of proximal teacher development. Teaching and Teacher Education, 27(2), 252-258. http://dx.doi.org/10.1016/j.tate.2010.08.008

Wells, G. (1999). Dialogic inquiry: Towards a sociocultural practice and theory of education. Cambridge University Press. http://dx.doi.org/10.1017/CBO9780511605895 
Hashemi Shahraki, S., Ketabi, S., \& Barati, H. 